\title{
HLA-DR antigens on human macrophages from bronchoalveolar lavage fluid
}

\author{
U COSTABEL, KJ BROSS, R ANDREESEN, H MATTHYS \\ From the Medizinische Klinik der Albert-Ludwigs-Universität, Freiburg, West Germany
}

ABSTRACT The expression of HLA-DR (Ia-like) antigens on human macrophages was investigated by analyses of cells from bronchoalveolar lavage fluid obtained from 12 patients with pulmonary sarcoidosis, six patients with extrinsic allergic alveolitis, nine patients with cryptogenic fibrosing alveolitis, 11 normal non-smokers, and 12 normal smokers. The HLA-DR antigen was demonstrated by the mouse monoclonal antibody OKIa by a peroxidase-antiperoxidase method performed on glass slides. No differences were found in the percentage of alveolar macrophages that expressed DR antigens between the five study groups. OKIa positivity was observed on more than $90 \%$ of macrophages in all cases. These observations suggest that the previously reported enhanced antigen presentation by alveolar macrophages in sarcoidosis is not linked with an increase in the percentage of $\mathrm{DR}^{+}$macrophages in the lung.

The expression of HLA-DR (Ia-like) antigens on cells of the monocyte/macrophage lineage is important for effective macrophage/T lymphocyte interactions, ${ }^{1}$ especially in the presentation of antigen by macrophages to lymphocytes. ${ }^{1-4}$ In patients with sarcoidosis the antigen presenting function of alveolar macrophages appears to be enhanced. ${ }^{56}$ The question of whether this might be accompanied by increased expression of HLA-DR antigens on alveolar macrophages has been raised, and indeed a recent study reported that patients with sarcoidosis and those with fibrosing alveolitis had a higher percentage of alveolar macrophages expressing DR antigens than normal non-smokers. ${ }^{7}$ These investigators found a rather low percentage of $\mathrm{DR}^{+}$macrophages in their normal study population $(21 \%)$. Other studies have shown, however, that almost all alveolar macrophages obtained from normal volunteers express HLA-DR antigens. $^{89}$

Because of these discordant reports, it was the aim of this study to compare the expression of HLA-DR antigens on macrophages obtained from a group of normal control patients with those obtained from groups of patients with sarcoidosis, extrinsic allergic alveolitis, and fibrosing alveolitis.

\footnotetext{
Address for reprint requests: Dr Ulrich Costabel, Abteilung Pulmologie, Medizinische Universitätsklinik, Hugstetterstr 55, D-7800 Freiburg, West Germany.
}

Accepted 13 September 1985

\section{Methods}

\section{PATIENTS}

Twelve untreated patients with pulmonary sarcoidosis were investigated (mean age 39 (SD 14), range 19-62 years). They all had a clinical picture consistent with this disease along with biopsy evidence of noncaseating, epitheloid cell granulomas, and no evidence of mycobacterial, fungal, or parasitic infection, or exposure to organic or inorganic dusts. Chest radiographs were type I in six patients, type II in three patients, and type III in three patients. There was only one smoker in this group. Seven patients had an increased ratio of helper and inducer $\left(\mathrm{OKT} 4^{+}\right)$to suppressor and cytotoxic $\left(\mathrm{OKT}^{+}\right) \mathrm{T}$ cells in bronchoalveolar lavage fluid (above 3.5-that is, above the mean +2 SD of our normal control values).

Six patients had untreated extrinsic allergic alveolitis (mean age 49 (16), range 21-67 years). All were non-smokers. The diagnosis was based on history and clinical and radiological features, and on respiratory function test results consistent with an interstitial lung disease. Serum from all six patients contained precipitins against the relevant antigens. Four patients were budgerigar fanciers, one patient had farmer's lung, and one patient had humidifier lung. Only one patient was studied during an acute episode.

Nine patients with cryptogenic fibrosing alveolitis (idiopathic pulmonary fibrosis) were studied (mean age 57 (19), range 18-81 years). Two patients were 
receiving immunosuppressive treatment when they were investigated. All were non-smokers. All patients with known causes of pulmonary fibrosis were excluded from this group - that is, those with organic or inorganic dust disease, drug induced interstitial lung disease, histiocytosis X, or collagen disorders. Lung function tests showed restrictive ventilatory defects and reduced diffusing capacity in these patients.

As control subjects, 11 normal non-smokers (mean age 37 (15), range 16-61 years) and 12 normal, symptomless smokers (mean age 34 (16), range 16-69 years) were studied. The smokers had an average smoking history of 14 (SD 9) pack years. All subjects had normal chest radiographs and normal lung function with the exception of one smoker, who had mild central airways obstruction.

\section{BRONCHOALVEOLAR LAVAGE}

Bronchoalveolar lavage was performed as previously described. ${ }^{10-12}$ After informed consent had been obtained from all patients and control subjects, a total of $100 \mathrm{ml}$ of $0.9 \%$ saline in five $20 \mathrm{ml}$ aliquots was instilled into the middle lobe or the lingula with a flexible bronchoscope. The fluid was immediately aspirated and filtered through gauze. The recovered cells were counted, washed three times in Eagle's minimum essential medium containing $0.2 \%$ bovine serum albumin and $0.1 \%$ EDTA, and resuspended in Eagle's medium. A trypan blue exclusion test for cell viability was performed. The cell viability was between $80-95 \%$. Before the first washing differential counts were made from smears stained with May-GrünwaldGiemsa by counting $600-1000$ cells.

IDENTIFICATION OF CELL SURFACE ANTIGENS The cell suspensions were transferred on to glass slides coated with poly-L-lysine for staining of cell surface antigens by the peroxidase-antiperoxidase method, ${ }^{13}$ a glass slide assay being used. ${ }^{11} 1415$ Briefly, $10 \mu \mathrm{l}$ cell suspension $\left(2 \times 10^{6}\right.$ cells $\left./ \mathrm{ml}\right)$ was added to poly-Llysine coated reaction areas of siliconised glass slides. After 10 minutes the cells were settled and firmly attached to the glass surface. After fixation with $0.05 \%$ glutaraldehyde for 20 minutes immunocytochemical staining was carried out. For this study the following murine monoclonal antibodies (Ortho Pharmaceutical Corporation) were used: OKIa for recognition of HLA-DR antigens on cells of the mononuclear phagocyte system, ${ }^{16}$ OKT4 for helperinducer T cells, ${ }^{17}$ and OKT8 for suppressor-cytotoxic $T$ cells. ${ }^{18}$ To evaluate the reaction, the slides were viewed under a light microscope with a magnification of 400-1000. A positive reaction was denoted by the presence of a dark brown, granular staining of the cell membrane. At least 200 cells were counted in each reaction area.

\section{STATISTICS}

All data are expressed as mean values with standard deviations in parentheses. Comparisons between groups were made with Student's two tailed $t$ test.

\section{Results}

GENERAL CHARACTERISTICS OF LAVAGE FLUID The total numbers of cells recovered from all disease groups and from the smoking controls were $\vec{\bullet}$ significantly greater than those from normal non- o smokers (table). The cell differential counts showed a predominance of lymphocytes in lavage fluid from patients with sarcoidosis and from those with extrinsic allergic alveolitis, and a predominance of polymorphonuclear leucocytes from the group with cryp- $\frac{\varnothing}{\varnothing}$ togenic fibrosing alveolitis (table). The ratio of $\varrho$ $\mathrm{OKT}^{+}$to $\mathrm{OKT}{ }^{+} \mathrm{T}$ cells was appreciably increased $\stackrel{\overrightarrow{0}}{\overrightarrow{0}}$ in lavage fluid obtained from the patients with sar- 3 coidosis (mean ratio $8.7(8.2)$ ) and this differed significantly $(2 p<0.001)$ from the ratio for the patients with extrinsic allergic alveolitis, which was reduced to $1.0(0.6)$.

\section{HLA-DR ANTIGENS ON LAVAGE FLUID MACROPHAGES}

There was no significant difference in the percentage of macrophages that expressed DR antigens between the different study groups. OKIa positivity was observed on virtually all macrophages $\left(>90 \%\right.$ in all $\frac{D}{0}$ cases; figs 1 and 2). The mean (SD) values for the different groups were: normal non-smokers $98.6 \%$ N $(2.3 \%)$, normal smokers $97.9 \%(2.2 \%)$, sarcoidosis N

General characteristics of lavage (BAL) fluid (mean values with standard deviations in parentheses)

\begin{tabular}{|c|c|c|c|c|c|}
\hline \multirow[t]{2}{*}{ Group } & $\begin{array}{l}\text { BAL fluid recovered } \\
(\%)\end{array}$ & $\begin{array}{l}\text { Total cells } \\
\left(\times 10^{6}\right)\end{array}$ & Macrophages & Lymphocytes & $\begin{array}{l}\text { Polymorphonuclear } \\
\text { cells }\end{array}$ \\
\hline & & & $(\%$ of total $c$ & & \\
\hline $\begin{array}{l}\text { Normal non-smokers }(n=11) \\
\text { Normal smokers }(n=12) \\
\text { Sarcoidosis }(n=12) \\
\text { Extrinsic allergic alveolitis }(n=6) \\
\text { Fibrosing alveolitis }(n=9)\end{array}$ & $\begin{array}{l}54(15) \\
52(13) \\
61(14) \\
53(9) \\
51(17)\end{array}$ & $\begin{array}{l}7(3) \\
23(13) \\
18(9) \\
29(17) \\
19(15)\end{array}$ & $\begin{array}{l}92(4) \\
96(3) \\
61(18) \\
27(11) \\
68(20)\end{array}$ & $\begin{array}{c}7(3) \\
3(2) \\
37(18) \\
60(14) \\
13(11)\end{array}$ & $\begin{array}{l}1(1) \\
1(1) \\
2(2) \\
13(10) \\
19(19)\end{array}$ \\
\hline
\end{tabular}




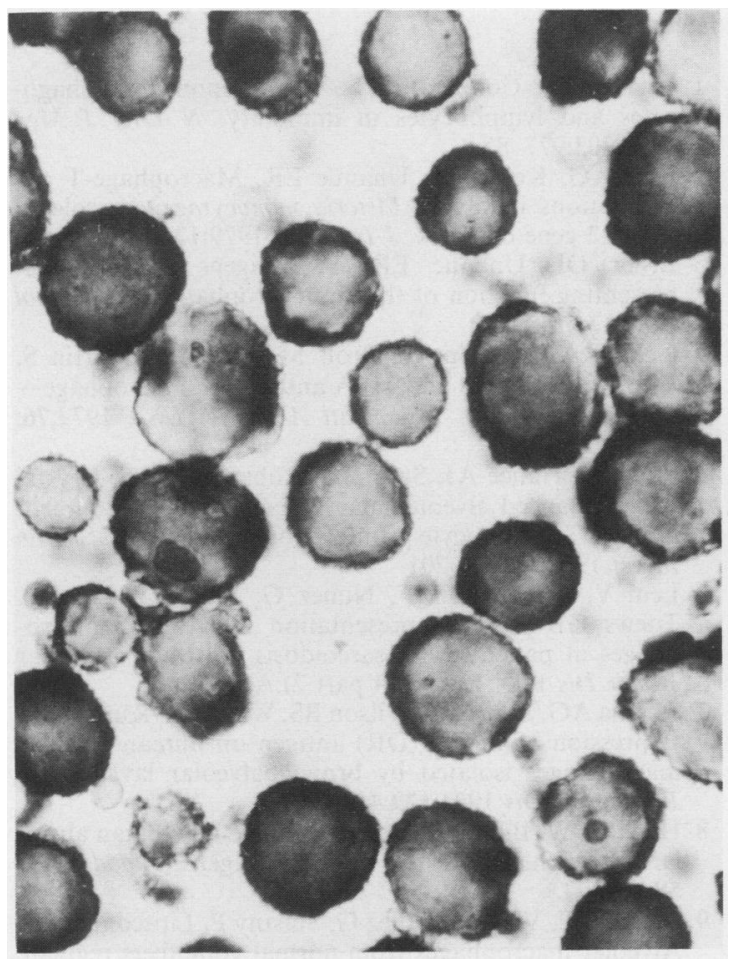

Fig 1 Bronchoalveolar fluid cells from a normal nonsmoker. The large cells are alveolar macrophages, virtually all of them positive for OKIa-that is, they have intense, dark brown staining on their surface. (Peroxidaseantiperoxidase method performed on glass slides, staining with the monoclonal antibody OKIa; $\times 565$.)

\section{$\mathrm{OKIa}^{+}$Macrophages}

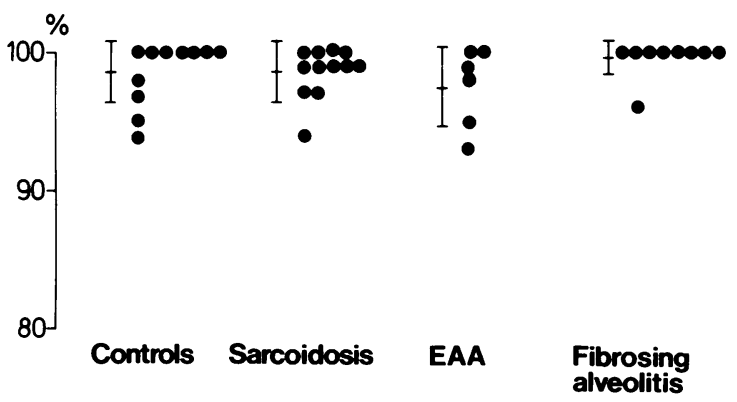

Fig 2 Percentages of macrophages expressing $H L A-D R$ surface antigen assessed by reaction with OKIa monoclonal antibody in non-smoking control subjects and in patients with sarcoidosis, extrinsic allergic alveolitis (EAA), and fibrosing alveolitis.
98.6\% (2.3\%), extrinsic allergic alveolitis $97.5 \%$ (2.9\%), cryptogenic fibrosing alveolitis $99.6 \%$ (1.3\%). Moreover, there was no difference in the percentage of $\mathrm{OKIa}^{+}$macrophages when the patients with sarcoidosis were divided into those with a raised OKT4/OKT8 ratio $(n=7)$ and those with a normal ratio $(n=5)$; the percentages of $\mathrm{OKIa}^{+}$macrophages in these two groups were 98.0 (2.2) and $99.4(0.5)$.

\section{Discussion}

Immunoregulatory activities are mediated, in part, by intercellular signals based on products of the I region (Ia antigen) of the major histocompatibility complex (MHC) in the mouse. The corresponding human Ia like antigens are HLA-DR gene products belonging to MHC class II antigens. Such HLA-DR antigens are expressed on monocytes and macrophages, B cells, and activated $T$ cells after allogenic or mitogenic stimulation, but not on resting $\mathrm{T}$ cells. ${ }^{1-41619}$

Local replication of $\mathrm{T}$ lymphocytes in the alveolar structures is widely held to lead to an expansion in lung $T$ cell numbers in patients with sarcoidosis. ${ }^{50}$ Most of these $\mathrm{T}$ cells are $\mathrm{OKT}^{+}{ }^{+}$helper-inducer cells. ${ }^{101121}$ They spontaneously secrete interleukin $2 .{ }^{22}$ Since $\mathrm{OKT} 4^{+}$cells are capable of proliferating in response to HLA-DR antigens, the process of antigen presentation by which HLA-DR positive mononuclear phagocytes interact with antigen and induce $T$ lymphocytes to proliferate might be increased in the lungs of patients with sarcoidosis. Indeed, enhanced antigen presentation by alveolar macrophages obtained from patients with sarcoidosis has recently been found. ${ }^{56}$ We do not know whether this process is accompanied by increased expression of HLA-DR antigens on alveolar macrophages.

In the present study no differences in the percentage of alveolar macrophages expressing HLA-DR antigens were found in the five study groups. OKIa positivity was observed on almost all macrophages from patients with sarcoidosis, extrinsic allergic alveolitis, and cryptogenic fibrosing alveolitis and from normal subjects. In our study smoking did not appear to influence the expression of HLA-DR antigens on macrophages. This observation differs from that of Lawrence $e$ al $^{23}$ who reported that smoking decreases DR antigen expression on human alveolar macrophages. These authors used an immunofluorescent technique, which might explain the discrepancy because smokers' macrophages are known to show autofluorescence. ${ }^{2425}$ This might interfere with the interpretation of the specific fluorescence of surface markers.

The finding of a very high percentage of $\mathrm{DR}^{+}$macrophages in lavage fluid from normal subjects confirms results from other centres. ${ }^{89}$ The absence of 
a difference in DR expression between alveolar macrophages from normal subjects and from patients with sarcoidosis is in agreement with a recent report by Venet et al. ${ }^{5}$ Razma et al, ${ }^{7}$ however, detected a higher percentage of $\mathrm{DR}^{+}$macrophages in the lavage fluid from patients with sarcoidosis and from patients with diffuse interstitial pulmonary fibrosis than in lavage fluid from normal non-smokers. This discordance may be due to different methods. Firstly, we applied an immunoperoxidase assay based on the unlabelled antibody enzyme method, and thus is more sensitive than the direct immunofluorescence used by Razma et al. ${ }^{7}$ Our technique may have identified cells that expressed small amounts of HLA-DR antigens on their surface. Secondly, Razma et al studied adherent macrophages after a 24 hour culture period, rather than macrophage preparations made immediately after lavage. Cells in culture may alter their surface marker characteristics. On the other hand, Lipscomb et $a l^{26}$ reported that extended culture for 13 days did not change the percentage of $\mathrm{DR}^{+}$alveolar macrophages. Thus we must consider other factors to explain the disparate results in surface expression of DR antigens on human alveolar macrophages. Differences in the reactivity and specificity of the different antiDR-antibodies used by different groups as well as the fact that interpretation of positivity may be very subjective may also account for the differences between the results of these studies.

Our method offers advantages other than increased sensitivity by comparison with immunofluorescence techniques; these include the production of permanent preparations and the capacity to investigate several antibodies in parallel as small numbers of cells are needed for each test. ${ }^{1415}$

We conclude from this study that the enhanced antigen presentation by alveolar macrophages in sarcoidosis $^{56}$ is not linked with an increase in the percentage of HLA-DR ${ }^{+}$macrophages in the lung. We cannot, however, exclude the possiblity that the total amount of DR antigen expressed by a single macrophage might be increased. This question should be investigated by quantitative methods such as radioimmunoassay or ELISA techniques. Currently, no established assays are available, but the development of an ELISA technique for quantitating DR antigens and other cell surface antigens is in preparation ( $G$ Dölken, personal communication). Such quantitative measurements of cell surface markers and their correlation with the functional properties of cells concerned in local immunoregulation should prove helpful in expanding our understanding of hitherto unresolved questions in immune diseases of the lung.

This work was supported by the Deutsche Forschungsgemeinschaft.

\section{References}

1 Unanue ER. Cooperation between mononuclear phagocytes and lymphocytes in immunity. $N$ Engl $J$ Med 1980;303:977-85.

2 Farr AG, Keily JM, Unanue ER. Macrophage-T cell $\frac{\bar{\sigma}}{\bar{T}}$ interactions involving Listeria monocytogenes-role of $\frac{\text { क }}{7}$ the H-2 gene complex. J Immunol 1979;122:2395-404.

3 Beller DI, Unanue ER. Ia antigens and antigenpresenting function of thymic macrophages. J Immunol $\omega$ 1980;124:1433-40.

4 Geha RA, Milgrom H, Broff M, Alpert S, Martin S, Yunis EJ. Effect of anti-HLA antisera on macrophage- $\vec{\omega}$ T cell interaction. Proc Natl Acad Sci USA 1979;76: 4038-41.

5 Venet A, Hance AJ, Saltini C, Robinson BWS, Crystal RG. Enhanced alveolar macrophage-mediated antigen- $\stackrel{A}{\rightarrow}$ induced $\mathrm{T}$ lymphocyte proliferation in sarcoidosis. J Clin Invest 1985;75:293-301.

6 Lem V, Lipscomb MF, Nunez G, Ball T, Stastny P, Toews GB. Antigen presentation by alveolar macro- 음 phages in patients with sarcoidosis [abstract]. $\mathrm{Am} \mathrm{Rev}$ Respir Dis 1984;129(No 4 part 2):A20.

7 Razma AG, Lynch JP, Wilson BS, Ward PA, Kunkel SL. Expression of Ia-like (DR) antigen on human alveolar macrophages isolated by bronchoalveolar lavage. $A m \vec{\theta}$ Rev Respir Dis 1984;129:419-24.

8 Hocking W, Billing R, Foon K, Golde D. Human alveolar macrophages express Ia-like antigens. Blood 1981; 58:1040-2.

9 Toews GB, Vial W, Nunez G, Stastny P, Lipscomb MF. Alveolar macrophages from normal volunteers regulate T lymphocyte responses [abstract]. Am Rev Respir Dis $\frac{\mathrm{Q}}{\mathrm{Q}}$ 1982;125(No 4 part 2):54.

10 Costabel U, Bross KJ, Matthys H. Pulmonary sarcoid- $\overrightarrow{\bar{O}}$ osis: assessment of disease activity by lung lymphyocyte 3 subpopulations. Klin Wochenschr 1983;61:349-56.

11 Costabel U, Bross KJ, Rühle KH, Löhr GW, Matthys H. Ia-like antigens on $\mathrm{T}$-cells and their subpopulations in pulmonary sarcoidosis and in hypersensitivity pneumonitis. Am Rev Respir Dis 1985;131:337-42.

12 Weinberger SE, Kelman JA, Elson NA, et al. Bron- ֻٕญ choalveolar lavage in interstitial lung disease. Ann Intern 0 Med 1978;89:459-66.

13 Sternberger LA. The unlabelled antibody enzyme method. In: Sternberger LA, ed. Immunocytochemistry. Englewood, NJ: Prentice-Hall, 1974:129.

14 Bross KJ, Pangalis GA, Staatz CG, Blume KG. Demon- 음 stration of cell surface antigens and their antibodies by the peroxidase-antiperoxidase method. Transplantation 1978;25:331-4.

15 Costabel U, Bross KJ, Matthys $H$. The immuno- $N$ peroxidase slide assay - a new method for the demonstration of surface antigens on bronchoalveolar lavage cells. Bull Eur Physiopathol Respir 1985;21:381-7.

16 Reinherz EL, Kung PC, Pesando JM, Ritz J, Goldstein G, Schlossman SF. Ia deterrninants on human T-cell subsets defined by monoclonal antibody: activation stim- $\frac{\text { CO }}{\mathrm{C}}$ uli required for expression. J Exp Med 1979;150:1472-82.

17 Reinherz EL, Kung PC, Goldstein G, Schlossman SF.Further characterization of the human inducer $T$ cell $T$ subset defined by monoclonal antibody. J Immunol 1979; 123:2894-6.

18 Reinherz EL, Kung PC, Goldstein G, Schlossman SF. A $\stackrel{\rho}{\Phi}$ monoclonal antibody reactive with the human cytotoxic/ suppressor $\mathrm{T}$ cell subset previously defined by a hetero-




antiserum termed $\mathrm{TH}_{2} . J$ Immunol 1980;124:130-7.

19 Winchester RJ, Kunkel HG. The human Ia system. $A d v$ Immunol 1979;28:221-92.

20 Crystal RG, Bitterman PB, Rennard SI, Hance AJ, Keogh BA. Interstitial lung diseases of unknown cause: disorders charaterized by chronic inflammation of the lower respiratory tract. $N$ Engl J Med 1984;310:154-66 and $235-44$.

21 Hunninghake GW, Crystal RG. Pulmonary sarcoidosis: a disorder mediated by excess helper T-lymphocyte activity at sites of disease activity. $N$ Engl J Med 1981; 305:429-34.

22 Pinkston P, Bitterman PB, Crystal RG. Spontaneous release of interleukin-2 by lung $\mathrm{T}$ lymphocytes in active pulmonary sarcoidosis. $N$ Engl J Med 1983;308:793-800.
23 Lawrence EC, Fox TB, Hall BT, Martin RR. Deleterious effect of cigarette smoking on expression of Ia antigens by human pulmonary alveolar macrophages [abstract]. Clin Res 1983;31:418A.

24 Martin RR. Altered morphology and increased acid hydrolase content of pulmonary macrophages from cigarette smokers. Am Rev Respir Dis 1973;107:596-601.

25 Edelson J, Klein M, Gallagher B, et al. Bronchoalveolar lavage cells autofluoresce [abstract]. Am Rev Respir Dis 1984;129 (No 4 part 2):Al64.

26 Lipsconıb MF, Lyons CR, Nunez G, et al. Human alveolar macrophages synthesize HLA-DR antigens in culture [abstract]. Am Rev Respir Dis 1983;127 (No 4 part 2):A59. 